\title{
GAMBARAN TUNTUTAN PEKERJAAN (JOB DEMANDS) DAN DUKUNGAN PEKERJAAN (JOB RESOURCES) PADA PEGAWAI INSTITUSI X DKI JAKARTA
}

\author{
Wistrianti Lestari ${ }^{1}$, Zamralita ${ }^{2}$ \\ ${ }^{1}$ Fakultas Psikologi, Universitas Tarumanagara \\ Email: wistri.badra@gmail.com²Fakultas Psikologi, Universitas Tarumanagara \\ Email: zamralita@fpsi.untar.ac.id
}

\begin{abstract}
ABSTRAK
Institusi X di DKI Jakarta merupakan ujung tombak pengelolaan pendapatan daerah dalam pemungutan pajak dan retribusi di Jakarta. Pembangunan dapat terhambat jika pendapatan daerah tidak optimal. Tuntutan Insitusi X semakin meningkat dan dukungan pekerjaannya semakin beragam sehingga dapat mempengaruhi efektifitas dalam bekerja. Bakker dan Demerouti (2008) mengembangkan model mengenai tuntutan pekerjaan (job demands) dan dukungan pekerjaan (job resources) dalam The Job Demands Resources Model (JD-R Model).The JD-R Model, menyatakan bahwa asumsi pertama dari teori $J D-R$ adalah karakteristik pekerjaan dapat dibagi dalam 2 kategori yang berbeda, yaitu job demands dan job resources. Asumsi kedua adalah Job demands dapat mengakibatkan kelelahan. Sebaliknya, job resources berkaitan dengan hal-hal yang memotivasi karyawan (Bakker \& Demerouti, 2014). Penelitian mengenai JD-R sejauh ini lebih banyak dilakukan pada perusahaan swasta dan masih sedikit pada populasi di Indonesia. Oleh karena itu, Peneliti tertarik untuk mengkaji gambaran job demands dan job resources pada pegawai Institusi $X$ di DKI Jakarta yang merupakan institusi pemerintah di Indonesia. Hasil penelitian ini diharapkan dapat memperluas pengetahuan mengenai JD-R di Indonesia serta membantu Institusi $X$ dalam memahami aspek-aspek yang dapat memotivasi dan yang menjadi tekanan bagi pegawainya sehingga dapat memberikan intervensi yang sesuai agar dapat bekerja lebih efektif. Metode yang digunakan dalam penelitian ini adalah metode kuantitatif. Hasil penelitian menunjukkan bahwa cognitive demand merupakan dimensi job demands yang paling sering dialami pegawai Institusi X di DKI Jakarta dan yang tidak sering dialami adalah dimensi role conflict. Sedangkan dimensi job resources yang sering dialami adalah coaching dan yang paling tidak sering dialami adalah autonomy.
\end{abstract}

Kata kunci: job demand, job resources, JD-R Model, JD-R Theory.

\section{PENDAHULUAN}

\section{Latar Belakang}

Institusi X DKI Jakarta merupakan bagian dari pemerintah provinsi yang bertanggung jawab dalam pemungutan pajak dan retribusi di wilayah DKI Jakarta. Tugas Institusi X di DKI Jakarta sangat penting karena menjadi ujung tombak pendapatan daerah yang selanjutnya digunakan dalam pembangunan DKI Jakarta. Pembangunan dapat terhambat jika pendapatan daerah tidak optimal.

Institusi X di DKI Jakarta saat ini menangani 13 jenis pajak daerah. Jenis-jenis pajak tersebut adalah Pajak Kendaraan Bermotor (PKB), Bea Balik Nama Kendaraan Bermotor (BBN-KB), Pajak Bahan Bakar Kendaraan Bermotor (PBB-KB), Pajak Penerangan Jalan, pajak hotel, Pajak hiburan, pajak restoran, pajak reklame, pajak air tanah, pajak parkir, pajak rokok, Pajak Bumi dan Bangunan (PBB) dan Bea Perolehan atas Hak Tanah dan Bangunan (BPHTB). Masingmasing jenis pajak memiliki peraturan yang berbeda dan dapat berubah saat diperlukan. Pegawai Institusi X di DKI Jakarta dituntut untuk dapat memahami dan menguasai peraturan setiap jenis pajak.

Sebagian besar pegawai Institusi X tersebar pada Unit Pelayanan Pajak dan Retribusi Daerah di 
seluruh kecamatan di DKI Jakarta. Mereka berhadapan langsung dengan masyarakat dan menangani berbagai kasus di lapangan. Secara umum, pegawai Institusi X bertanggung jawab terhadap pemungutan pajak di areanya, melakukan pemeriksaan termasuk memberi sanksi pada Wajib Pajak (WP) yang melalaikan kewajibannya, serta menjajaki sumber pajak baru baik dari WP yang sudah ada maupun WP potensial. Selain itu, mereka juga harus mengatasi keluhan masyarakat serta menangani kasus sengketa pajak di areanya.

Tuntutan pekerjaan (job demands) pegawai Institusi $\mathrm{X}$ di DKI Jakarta saat ini meningkat dibandingkan tahun-tahun sebelumnya. Berdasarkan Laporan Keuangan Pemerintah Provinsi DKI Jakarta, target pendapatan pajak Institusi X tahun 2016 adalah 33,1 triliun atau hanya meningkat 580 milyar dari tahun sebelumnya. Namun, target pendapatan Institusi X tahun 2017 adalah 35 trilyun atau meningkat sebesar 2 trilyun dari tahun 2016. Penambahan target yang cukup signifikan pada Insitusi X memberikan dampak pada peningkatan tuntutan kerja pada para pegawainya. Jumlah jenis pajak yang harus ditangani juga bertambah. Sebelum tahun 2014, Institusi $X$ hanya menangani 7 jenis pajak. Saat ini, ada 13 jenis pajak yang harus ditangani. Penambahan jenis pajak tersebut berasal dari pajak pemerintah pusat dan dari institusi lain di lingkungan Pemprov DKI Jakarta. Jenis pajak baru tersebut diantaranya adalah PBB dan BPHTB yang berasal dari pemerintah pusat serta pajak parkir dan pajak penerangan jalan yang berasal dari institusi lain di Pemprov DKI Jakarta. Penambahan jenis pajak yang harus dikelola oleh Institusi $\mathrm{X}$ tidak diimbangi dengan penambahan pegawai, sehingga menambah tuntutan pekerjaan pada masing-masing pegawainya. Sejak era kepemimpinan Gubernur Basuki Tjahja Purnama (Ahok), pegawai Institusi X dapat menerima tunjangan insentif jika mencapai target pendapatan pajak yang ditentukan. Sebelumnya, pegawai Institusi $\mathrm{X}$ bekerja tanpa ada target yang harus dicapai. Hal tersebut menyebabkan tuntutan pekerjaan pegawai Institusi X makin meningkat.

Dukungan pekerjaan (job resources) yang diterima pegawai Institusi $\mathrm{X}$ semakin beragam. Sebelum tahun 2015, pegawai Institusi X tidak menerima tunjangan apapun yang terkait dengan kinerja. Saat ini pegawai Institusi $X$ dapat menerima tunjangan insentif yang cukup besar jika mencapai target pendapatan pajak yang ditetapkan. Tunjangan tersebut diterima setiap 3 bulan berdasarkan pencapaian target. Hal tersebut merupakan bentuk penghargaan bagi pegawai yang memiliki kinerja baik. Selain itu, kesempatan untuk mendapatkan kenaikan jabatan lebih terbuka dengan sistem lelang jabatan. Setiap pegawai yang berkompeten memiliki kesempatan untuk menduduki jabatan yang lebih tinggi, tidak hanya berdasarkan kedekatan dengan pimpinan. Pegawai Institusi X juga diberi kesempatan mendapatkan beasiswa untuk belajar ke jenjang S2 dan mengikuti pelatihan-pelatihan yang diperlukan.

Bakker dan Demerouti (2008) merupakan tokoh-tokoh yang mengembangkan model mengenai tuntutan pekerjaan (job demands) dan dukungan pekerjaan (job resources) dalam The Job Demands Resources Model (JD-R Model). Beberapa tahun terakhir, jumlah penelitian mengenai $J D-R$ Model meningkat sehingga model ini sudah berkembang menjadi teori (Bakker \& Demerouti, 2014). Beberapa penelitian menggunakan teori ini sebagai kerangka konseptual, menganalisis permasalahan ataupun dasar intervensi dalam organisasi (Schaufeli, 2017).

Teori JD-R memiliki 2 asumsi. Asumsi pertama dari teori JD-R adalah lingkungan kerja atau karakteristik pekerjaan dapat dibagi dalam 2 kategori yang berbeda, yaitu job demands dan job resources. Job demands adalah aspek fisik, psikologis, sosial dan organisasi dari pekerjaan yang membutuhkan usaha untuk mencapainya dan berdampak pada aspek fisik atau psikologis tertentu. Beberapa dimensi dari job demands adalah tekanan pekerjaan yang tinggi (work 
pressure), kondisi emosi yang terkait dengan pekerjaan (emotional demand), kerumitan dalam pekerjaan (hassle), konflik peran (role conflict) dan kondisi pekerjaan yang membutuhkan pemikiran yang akurat (cognitive demand). Job resources merujuk pada aspek fisik, sosial atau organisasi dari pekerjaan yang dapat: (a) berpengaruh pada pencapaian tujuan, (b) mengurangi job demand serta aspek fisik dan psikologis yang menyertainya, (c) menstimulasi pengembangan dan pembelajaran (Bakker \& Demerouti, 2014). Beberapa dimensi pada job resources adalah otonomi dalam bekerja (autonomy), dukungan sosial (social support), umpan balik (feedback), kesempatan untuk berkembang (opportunities for development), bimbingan dari atasan (coaching). Asumsi kedua teori JD-R adalah terdapat dua proses yang berpengaruh pada tekanan (pressure) dan motivasi dalam pekerjaan. Job demands dapat mengakibatkan kelelahan dan keluhan kesehatan lainnya, sehingga berkaitan dengan tekanan pada pekerjaan. Sebaliknya, job resources berkaitan dengan hal-hal yang secara potensial memotivasi karyawan sehingga berdampak pada hasil yang positif seperti peningkatan kepuasan kerja dan keterikatan kerja. (Bakker \& Demerouti, 2014).

Penelitian di beberapa organisasi menyatakan bahwa job demands yang tinggi mengakibatkan kelelahan mental dan fisik karyawan (Bakker, Demerouti, Euwema, 2005). Job demands menjadi stressor dalam pekerjaan pada saat karyawan membutuhkan usaha yang tinggi dan tidak melakukan recovery secara tepat (Meijman \& Mulder dalam Bakker, Demerouti, Hakanen, Xanthoupoulou, 2007). Beberapa studi menunjukkan job demands berhubungan dengan burnout dan sebaliknya burnout berhubungan dengan job demands (Demerouti, Le Blanc, Bakker, Schaufeli, \& Hox, 2009). Selain itu, Van den Broeck, De Cuyper, De Witte \& Vansteenkiste (2010) juga menyatakan bahwa terdapat hubungan yang negatif antara job demand dan keterikatan kerja meski tidak secara spesifik disebutkan dalam JD-R model.

Beberapa penelitian secara konsisten menunjukkan bahwa job resources berhubungan secara positif dengan work engagement (Bakker \& Demerouti, 2008; Schaufeli \& Salanova dalam Bakker, 2009). Job resources juga lebih baik dalam memprediksi keterikatan kerja dibandingkan job demands (Bakker, 2009). Studi longitudinal menunjukkan bahwa perubahan pada job resources memprediksi keterikatan kerja dalam periode 1 tahun (Schaufeli, Bakker \& Van Rhenen, 2009). Job resources dapat berperan sebagai motivasi intrinsik (meningkatkan proses belajar dan pengembangan diri) ataupun ekstrinsik (berperan sebagai pendorong dalam pencapaian target) (Bakker, 2009). Bakker et al (2005) menyatakan bahwa job resouces merupakan hal yang penting dalam menjaga keterikatan kerja saat kondisi job demands tinggi. Job resources menjadi penyangga (buffer) bagi dampak dari job demands (Bakker \& Demerouti, 2014). Selain itu, job resources memiliki efek yang bermakna pada keterikatan kerja dalam kondisi job demand tinggi (Hakkanen, Bakker \& Demerouti, 2005).

Salah satu penelitian di Indonesia mengenai JD-R dilakukan oleh Erfiani (2015) yang melibatkan 194 pegawai call centre. Dalam penelitian tersebut, dimensi job demands yang paling sering dialami responden adalah cognitive demands sedangkan dimensi yang tidak terlalu sering dialami adalah role conflict. Untuk job resources, dimensi yang paling sering dialami adalah social support dan yang paling tidak sering dialami adalah coaching.

Penelitian-penelitian mengenai job demand dan job resources sejauh ini lebih banyak dilakukan pada perusahaan swasta dan masih sedikit pada populasi di Indonesia. Oleh karena itu, Peneliti tertarik untuk mengkaji gambaran job demand dan job resources pada pegawai Institusi X di Pemprov DKI Jakarta yang merupakan institusi pemerintah di Indonesia. Peneliti juga ingin mengetahui perbedaan gambaran dimensi job demand dan job resources pada pegawai call 
centre dalam penelitian Erfiani (2015) dengan pegawai pada Institusi X. Hasil penelitian ini diharapkan dapat memperluas pengetahuan dan wawasan mengenai job demand dan job resources di Indonesia serta teori JD-R secara umum. Peneliti juga berharap hasil penelitian ini dapat memberikan kontribusi bagi organisasi. Dengan mengetahui gambaran job demands dan job resource para pegawainya, Institusi $\mathrm{X}$ dapat memahami aspek-aspek yang dapat memotivasi dan yang menjadi tekanan bagi pegawainya sehingga dapat memberikan intervensi yang sesuai agar dapat bekerja lebih efektif.

\section{METODE PENELITIAN}

\section{Karakteristik Partisipan}

Karakteristik partisipan dalam penelitian ini adalah pegawai Institusi X DKI Jakarta , berusia 2558 tahun dan memiliki masa kerja minimal 1 tahun. Jumlah keseluruhan partisipan adalah 176 orang yang berasal dari Institusi $\mathrm{X}$ di kantor pusat dan unit pelayanan wilayah kecamatan (Jakarta Timur, Jakarta Selatan dan Jakarta Pusat). Penelitian menggunakan metode kuantitatif. Teknik sampling pada penelitian ini menggunakan purposive sampling karena pengambilan sampel dilakukan pada pegawai Institusi X saja di lingkungan Pemprov DKI Jakarta. Berikut ini adalah uraian mengenai data partisipan berdasarkan jenis kelamin, usia, masa kerja, pendidikan, status pernikahan, tingkat jabatan dan lokasi kerja.

Tabel 1. Gambaran data partisipan berdasarkan jenis kelamin

\begin{tabular}{ccc}
\hline Jenis Kelamin & Jumlah & Persentase \\
\hline Laki-laki & 103 & $58.5 \%$ \\
Perempuan & 73 & $41.5 \%$ \\
Total & $\mathbf{1 7 6}$ & $\mathbf{1 0 0 \%}$ \\
\hline
\end{tabular}

Tabel 2. Gambaran data partisipan berdasarkan usia

\begin{tabular}{ccc}
\hline Usia (tahun) & Jumlah & Persentase \\
\hline $25-29$ & 24 & 13.6 \\
$30-34$ & 53 & 30.1 \\
$35-39$ & 28 & 15.9 \\
$40-44$ & 24 & 13.6 \\
$45-49$ & 33 & 18.8 \\
$50-54$ & 13 & 7.4 \\
$55-58$ & 1 & 0.6 \\
\hline Total & $\mathbf{1 7 6}$ & $\mathbf{1 0 0}$ \\
\hline
\end{tabular}

Tabel 3. Gambaran data partisipan berdasarkan masa kerja

\begin{tabular}{ccc}
\hline Masa kerja (tahun) & Jumlah & Persentase \\
\hline $1-10$ & 122 & 69.3 \\
$11-20$ & 30 & 17 \\
$21-30$ & 22 & 12.5 \\
$31-40$ & 2 & 2 \\
Total & $\mathbf{1 7 6}$ & $\mathbf{1 0 0}$ \\
\hline
\end{tabular}


Tabel 4. Gambaran data partisipan berdasarkan tingkat Pendidikan

\begin{tabular}{ccc}
\hline Tingkat Pendidikan & Jumlah & Persentase \\
\hline SMA & 10 & $5.7 \%$ \\
Diploma & 24 & $13.6 \%$ \\
S1 & 103 & $58.5 \%$ \\
S2 & 39 & $22.2 \%$ \\
Total & $\mathbf{1 7 6}$ & $\mathbf{1 0 0 \%}$ \\
\hline
\end{tabular}

Tabel 5. Gambaran data partisipan berdasarkan status pernikahan

\begin{tabular}{ccc}
\hline Status Pernikahan & Jumlah & Persentase \\
\hline Lajang & 33 & $18.8 \%$ \\
Menikah & 140 & $79.5 \%$ \\
Duda/Janda & 3 & $1.7 \%$ \\
Total & $\mathbf{1 7 6}$ & $\mathbf{1 0 0 \%}$ \\
\hline
\end{tabular}

Tabel 6. Gambaran data partisipan berdasarkan tingkat jabatan

\begin{tabular}{ccc}
\hline Tingkat Jabatan & Jumlah & Persentase \\
\hline Kepala Bagian/Unit/Bidang & 3 & $1.7 \%$ \\
Kepala Sub Bagian/Seksi/Sub Bidang & 27 & $15.3 \%$ \\
Staff & 146 & $83 \%$ \\
Total & $\mathbf{1 7 6}$ & $\mathbf{1 0 0 \%}$ \\
\hline
\end{tabular}

Tabel 7. Gambaran data partisipan berdasarkan lokasi kerja

\begin{tabular}{ccc}
\hline Lokasi Kerja & Jumlah & Persentase \\
\hline Pusat & 29 & $16.5 \%$ \\
Wilayah & 147 & $83.5 \%$ \\
Total & $\mathbf{1 7 6}$ & $\mathbf{1 0 0 \%}$ \\
\hline
\end{tabular}

\section{Pengukuran}

Pengukuran tuntutan kerja (Job Demand) dan dukungan kerja (Job Resources) menggunakan Job Demand Resources Questionnaire (JDR) dari Bakker (2014). JDR Questionnaire memiliki 40 item yang terdiri dari 23 item mengukur job demand dan 17 item mengukur job resources. Job Demand memiliki reliabilitas internal 0.84 dan job resources memiliki reliabilitas internal 0.92 . Dimensi pada job demand adalah tekanan pekerjaan yang tinggi (work pressure), kondisi emosi yang terkait dengan pekerjaan (emotional demand), kerumitan dalam pekerjaan (hassle), konflik peran (role conflict) dan kondisi pekerjaan yang membutuhkan pemikiran yang kompleks (cognitive demand). Contoh butir dari dimensi emotional demand adalah, "Pekerjaan saya menyinggung hal-hal yang terkait dengan pribadi saya". Contoh butir dari dimensi hassle adalah, "Saya harus menghadapi beberapa hal yang merepotkan untuk menyelesaikan tugas". Contoh butir dari dimensi work pressure adalah, "Saya selalu mempunyai banyak pekerjaan yang harus diselesaikan". Contoh butir dari dimensi cognitive demand adalah, "Pekerjaan saya menuntut kehati-hatian dan ketepatan". Contoh butir dari dimensi role conflict adalah, "Saya tidak dapat 
memenuhi tuntutan tugas yang saling bertentangan dari rekan-rekan kerja saya". Dimensi pada Job Resources terdiri dari otonomi dalam bekerja (Autonomy), dukungan sosial (Social support), umpan balik (Feedback), kesempatan untuk berkembang (Opportunities for development), bimbingan dari atasan (Coaching). Contoh butir pada dimensi Autonomy adalah, "Saya memiliki keleluasaan untuk menyelesaikan tugas-tugas saya secara mandiri". Contoh butir pada dimensi social support adalah, "Saya dapat bertanya pada rekan kerja setiap saya membutuhkan bantuan". Contoh butir pada dimensi feedback adalah, "Saya mendapat informasi yang memadai mengenai sasaran tugas saya". Contoh butir pada dimensi opportunities for development adalah, "Dalam bekerja, saya memiliki kesempatan untuk mengembangkan potensi yang saya miliki". Contoh butir pada dimensi coaching adalah, "Atasan saya terbuka dalam menyampaikan penilaian hasil kerja saya."

\section{HASIL DAN PEMBAHASAN}

Data responden dianalisis dengan menggunakan descriptive statistic dan independent sample ttest. Kategori yang akan digunakan adalah sebagai berikut :(a) rendah $=$ skor rata-rata $1-1,99$ (b) Rata-rata $=$ skor $2-2,99$ (c) tinggi $=3-4,00$

\section{Gambaran Tuntutan Pekerjaan (Job Demands)}

Secara umum tuntutan pekerjaan pada pegawai Institusi X di DKI Jakarta tergolong rendah. Hal ini berarti aspek fisik, sosial atau organisasi dari pekerjaan yang membutuhkan usaha dari karyawan berada pada kategori rendah. Jika ditinjau dari tiap dimensi pada job demand, maka cognitive demand merupakan dimensi dengan kategori tinggi. Pegawai Institusi X di DKI Jakarta menangani 13 jenis pajak yang memiliki peraturan berbeda-beda dan menghadapi berbagai macam kasus pajak di lapangan, sehingga menuntut keakuratan dalam mengerjakannya. Kesalahan pemahaman pada peraturan pajak daerah dapat berakibat penurunan pendapatan pajak atau sengketa di pengadilan. Oleh karena itu cognitive demand merupakan dimensi yang paling sering dialami oleh pegawai Institusi X. Dimensi terendah pada job demand adalah role conflict. Struktur organisasi dan job description pekerjaan pada Institusi X di DKI Jakarta sudah cukup jelas, sehingga para pegawai Institusi $\mathrm{X}$ tidak sering mengalami role conflict di dalam organisasi. Gambaran job demands yang sering dan tidak sering dialami pada Institusi X sama dengan penelitian Erfiani (2015) pada responden call centre.

Tabel 8. Gambaran Tuntutan Pekerjaan (Job Demand)

\begin{tabular}{ccc}
\hline Job Demand & Mean & Kategori \\
\hline Emotional Demand & 1.90 & Rendah \\
Hassle & 2.01 & Rata-rata \\
Work Pressure & 2.90 & Rata-rata \\
Cognitive Demand & 3.00 & Tinggi \\
Role Conflict & 1.74 & Rendah \\
Total Job Demand & $\mathbf{1 . 9 8}$ & Rendah \\
\hline
\end{tabular}

\section{Gambaran Dukungan Pekerjaan (Job Resources)}

Pegawai Institusi X di DKI Jakarta memiliki dukungan pekerjaan yang tergolong tinggi. Ratarata pada dimensi dukungan pekerjaan relatif merata. Seluruh dimensi pada job resources tergolong tinggi. Job resources yang paling sering dialami oleh pegawai Institusi $\mathrm{X}$ adalah coaching, sedangkan yang paling tidak sering dialami adalah autonomy. Hasil tersebut berbeda dengan penelitian Erfiani (2015) yang melibatkan pegawai call centre. Penelitian pada pegawai 
call centre menunjukkan bahwa dimensi job resources yang paling sering dialami adalah social support sedangkan yang paling tidak sering dialami adalah coaching. Penjelasan mengenai hal tersebut adalah para pegawai Institusi $\mathrm{X}$ banyak menghadapi kasus-kasus di lapangan yang terkait dengan peraturan dan kebijakan perpajakan. Pegawai Institusi X yang sebagian besar berada di wilayah kecamatan tidak mudah untuk meminta bantuan kantor pusat jika menghadapi kasus-kasus yang terjadi. Fungsi coaching atasan menjadi sangat penting dalam mengatasi permasalahan operasional sehari-hari. Namun hal tersebut membuat para pegawai Institusi $\mathrm{X}$ tidak leluasa dalam memilih metode dalam menyelesaikan permasalahan dan tidak terlalu dilibatkan dalam proses pengambilan keputusan. Oleh karena itu autonomy menjadi dimensi yang paling tidak sering dialami oleh pegawai Institusi $X$.

Tabel 9. Gambaran Dukungan Pekerjaan (Job Resources)

\begin{tabular}{ccc}
\hline Job Resources & Mean & Kategori \\
\hline Coaching & 3.09 & Tinggi \\
Autonomy & 3.00 & Tinggi \\
Social Support & 3.08 & Tinggi \\
Feedback & 3.03 & Tinggi \\
Opprtunities for Development & 3.07 & Tinggi \\
Total Job Resource & $\mathbf{3 . 0 6}$ & Tinggi \\
\hline
\end{tabular}

\section{Gambaran job demands dan job resources berdasarkan lokasi kerja}

Sebagian besar pegawai Institusi X di DKI Jakarta berada di kantor wilayah. Secara umum, tidak ada perbedaan signifikan antara job demands di kantor wilayah dan kantor pusat. Cognitive demand pegawai pada kantor wilayah memiliki rata-rata lebih tinggi dari kantor pusat. Karakteristik pekerjaan di kantor wilayah agak sedikit berbeda dengan kantor pusat. Pegawai Institusi $\mathrm{X}$ pada kantor wilayah lebih sering menangani berbagai kasus pajak di lapangan sehingga rata-rata cognitive demand lebih tinggi.

Tidak ada perbedaan signifikan antara dukungan pekerjaan di kantor pusat dan wilayah. Dimensi tertinggi dukungan pekerjaan di kantor pusat adalah social support. Dimensi tertinggi dukungan kerja pada kantor wilayah adalah coaching. Kantor wilayah yang tersebar di kecamatankecamatan, sebagian besar berada jauh dari kantor pusat, sehingga penanganan permasalahan banyak dibantu oleh atasan langsung. 
Tabel 10. Gambaran job demands dan job resources berdasarkan lokasi kerja

\begin{tabular}{ccccc}
\hline Dimensi & $\begin{array}{c}\text { Mean Kantor } \\
\text { Pusat }\end{array}$ & $\begin{array}{c}\text { Mean Kantor } \\
\text { Wilayah }\end{array}$ & $\begin{array}{c}\text { Signifikansi } \\
<\mathbf{0 . 0 5}\end{array}$ \\
\hline Job & Emotional Demand & 1.90 & 1.90 & 0.975 \\
Demands & Hassle & 2.17 & 1.99 & 0.032 \\
& Work Pressure & 2.91 & 2.90 & 0.062 \\
& Cognitive Demand & 2.93 & 3.00 & 0.950 \\
& Role Conflict & 1.85 & 1.72 & 0.411 \\
& Total & $\mathbf{2 . 1 4}$ & $\mathbf{2 . 0 6}$ & $\mathbf{0 . 1 3 1}$ \\
\hline \multirow{3}{*}{ Rob } & Coaching & 2.99 & 3.11 & 0.350 \\
& Autonomy & 2.98 & 3.01 & 0.806 \\
& Social Support & 3.09 & 3.07 & 0.884 \\
& Feedback & 2.98 & 3.04 & 0.587 \\
& Opportunities for & 2.97 & 3.09 & 0.351 \\
& Development & & & \\
& Total & $\mathbf{3 . 0 0}$ & $\mathbf{3 . 0 7}$ & $\mathbf{0 . 4 9 4}$ \\
\hline
\end{tabular}

\section{Gambaran job demands dan job resources berdasarkan tingkat jabatan}

Pegawai Pemprov DKI Jakarta memiliki range golongan yang cukup banyak. Oleh karena itu penulis membagi 2 kategori dalam tingkat jabatan. Jabatan yang memiliki bawahan (pimpinan) dan yang tidak memiliki bawahan (staff). Pimpinan terdiri dari setingkat Kepala Seksi sampai dengan Kepala bagian.

Nilai rata-rata dimensi Cognitive Demand pada kedua tingkat jabatan menempati tempat teratas. Namun, nilai rata-rata cognitive demand pada pimpinan lebih tinggi dari staff. Secara umum, nilai rata-rata tuntutan pekerjaan pada pimpinan lebih tinggi dibanding staff, meski tidak ada perbedaan signifikan diantara keduanya.

Nilai rata-rata dukungan pekerjaan pada pimpinan lebih tinggi dibandingkan staff, meski tidak ada perbedaan signifikan diantara keduanya. Dimensi autonomy memiliki nilai rata-rata tertinggi pada pimpinan, sedangkan dimensi coaching merupakan dukungan pekerjaan tertinggi pada staff. Para pimpinan Institusi X di wilayah, memiliki otonomi untuk mengatur pekerjaannya, sehingga dimensi tersebut paling sering dialami oleh para pimpinan. Pada tingkat staff, autonomy mendapat urutan terendah, namun dimensi coaching mendapat urutan tertinggi pada dukungan pekerjaan. Meskipun tingkat staff kurang mendapat otonomi dalam pekerjaannya, mereka mendapatkan bimbingan dari atasannya sehingga dukungan pekerjaan tetap tinggi. 
Tabel 11. Gambaran job demands dan job resources berdasarkan tingkat jabatan

\begin{tabular}{ccccc}
\hline & Dimensi & $\begin{array}{c}\text { Mean } \\
\text { Pimpinan }\end{array}$ & $\begin{array}{c}\text { Mean } \\
\text { Staf }\end{array}$ & $\begin{array}{c}\text { Signifikansi } \\
<\mathbf{0 . 0 5}\end{array}$ \\
\hline Job & Emotional Demand & 1.93 & 1.89 & 0.601 \\
Demands & Hassle & 1.99 & 2.02 & 0.787 \\
& Work Pressure & 3.05 & 2.87 & 0.130 \\
& Cognitive Demand & 3.07 & 2.98 & 0.296 \\
& Role Conflict & 1.69 & 1.75 & 0.487 \\
& Total & $\mathbf{2 . 0 9}$ & $\mathbf{2 . 0 7}$ & $\mathbf{0 . 7 3 5}$ \\
\hline \multirow{3}{*}{ Rob } & Coaching & 3.2 & 3.07 & 0.330 \\
& Autonomy & 3.26 & 2.95 & 0.010 \\
& Social Support & 3.22 & 3.05 & 0.132 \\
& Feedback & 3.14 & 3.01 & 0.210 \\
& Opprtunities for & 3.19 & 3.04 & 0.263 \\
& Development & & & \\
& Total & $\mathbf{3 . 2 3}$ & $\mathbf{3 . 0 3}$ & $\mathbf{0 . 0 9 4}$ \\
\hline
\end{tabular}

\section{KESIMPULAN DAN SARAN}

\section{Kesimpulan}

Kesimpulan dari penelitian ini adalah pegawai Institusi X di DKI Jakarta secara umum memiliki job demands yang rendah dan job resources yang tinggi. Dimensi job demands yang paling sering dialami adalah cognitive demand, sedangkan dimensi yang paling tidak sering dialami adalah role conflict. Hasil penelitian tersebut sejalan dengan penelitian Erfiani (2015) yang melibatkan responden pegawai call centre. Namun perbedaan hasil penelitian terjadi pada dimensi Job Resources. Job resources yang paling sering dialami pada Institusi X adalah coaching dan yang paling tidak sering dialami adalah autonomy. Hal tersebut berbeda dengan penelitian Erfiani (2015) dimana social support menjadi dimensi job resources yang paling sering dialami dan coaching adalah dimensi job resources yang paling sering tidak dialami. Tidak ada perbedaan yang signifikan antara pegawai kantor wilayah dan pusat Institusi X, baik dalam job demands maupun job resources. Dimensi job demands yang memiliki nilai rata-rata tertinggi pada pegawai Institusi $\mathrm{X}$ wilayah dan pusat adalah cognitive demand. Nilai rata-rata cognitive demand pada pegawai Institusi $\mathrm{X}$ wilayah lebih tinggi dibanding pusat. Tidak ada perbedaan signifikan pada job demands dan job resources, baik pada tingkat pimpinan maupun staf. Dimensi tertinggi job demands pada tingkat pimpinan dan staf adalah cognitive demand, sedangkan dimensi job resources tertinggi pada tingkat pimpinan adalah autonomy dan pada tingkat staf adalah coaching.

\section{Saran}

Berdasarkan penelitian ini didapat gambaran job demands dan job resources pada pegawai Institusi X di DKI Jakarta. Gambaran tersebut dapat digunakan oleh Institusi X di DKI Jakarta untuk lebih mengembangkan dimensi job resources yang kurang optimal dan mengelola job demands agar para pegawai lebih efektif dalam bekerja. Selain itu, penulis juga menyarankan untuk melakukan penelitian lebih mendalam lagi dengan mencari efek job resources pada hubungan job demands dengan keterikatan kerja atau burnout. 


\section{Ucapan Terima Kasih}

Penulis mengucapkan terima kasih kepada Sekretariat Institusi X di DKI Jakarta yang telah mengijinkan untuk melakukan penelitian. Selain itu, penulis juga mengucapkan terima kasih kepada pegawai Institusi X di DKI Jakarta yang telah bersedia menjadi responden.

\section{REFERENSI}

Bakker, A.B. (2007). The job demands-resources model. Journal of Managerial Psychology, 22, 309-328.

Bakker, A.B. (2009). Building engagement in the workplace. In R.J. Burke \& C.L. Cooper (Eds.), The peak performing organization (pp. 50-72). Oxon, UK:Routledge.

Bakker, A.B. (2014). The job demands-resources questionnaire. Rotterdam: Erasmus University.

Bakker, A.B.,\& Demerouti E.(2008). Towards a model of work engagement. The Journal of Career Development International, 13(3). 209-219.

Bakker, A.B.,\& Demerouti, E. (2014). Job demands - resources theory. In P.Y Chen \& C.L Cooper (Eds.) Work and Wellbeing: A Complete Reference Guide, Vol III. New York, USA : John Wiley \& Sons, Ltd

Bakker, A.B., Demerouti, E.,\& Euwema, M.C. (2005). Job resources buffer the impact of job demands on burnout. Journal of Occupational Health Psychology, 10(2) 170-180

Bakker, A.B., Demerouti, E., Hakanen, JJ.,\& Xanthoupoulou, D. (2007). Job resources boost work engagement, particularly when job demands are high. Journal of Educational Psychology, 99(2) 274-284

Demerouti, E., Le Blanc, P.M., Bakker, A.B., Schaufeli, W.B., \& Hox, J. (2009). Present but sick: A three-wave study on job demands, presenteeism and burnout. Career Development International, 14, 50-68.

Erfiani, E. (2015). Peran Job Resources sebagai moderator diantara hubungan job demands dengan burnout pada pegawai call centre. Jakarta: Fakultas Psikologi Universitas Tarumanagara.

Gruman, A.G., Saks, A.M. (2010). Performance management and employee engagement. Human Resource Management Review ,21, 123-136

Schaufeli, W.B. (2017). Applying the job demands-resources model: A 'how to' guide to measuring and tackling work engagement and burnout. Organizational Dynamics 46, $120-132$

Pemerintah Provinsi DKI Jakarta. (2017). Laporan keuangan pemerintah provinsi DKI Jakarta tahun anggaran 2016 audited. Jakarta: Pemprov DKI Jakarta

Van den Broeck, A,. De Cuyper, N., De Witte, H., \&Vansteenkiste, M. (2010). Not all job demands are equal: Differentiating job hindrances and job challenges in the job demandsresources model. European Journal of Work and Organizational Psychology,(1), 1-25 